\title{
COMMUNITY PHARMACISTS AND COSMETICS: CURRENT STATE IN TURKEY
}

\author{
SERBEST ECZACILAR VE KOZMETIKKLER: \\ TÜRKIYY'DEKİ DURUM
}

\author{
Nazlı SENCAN ${ }^{1}$, Gülengül DUMAN ${ }^{2}$, Müge KOPARAN ${ }^{3}$ \\ ${ }^{1}$ Yeditepe University, Faculty of Pharmacy, Social Pharmacy Department, İstanbul - TURKEY. \\ ${ }^{2}$ Yeditepe University, Faculty of Pharmacy, Pharmaceutical Technology Department, \\ İstanbul - TURKEY. \\ ${ }^{3}$ ARAS Consultancy, İstanbul - TURKEY.
}

\section{ABSTRACT}

This study aims to determine community pharmacists' levels of knowledge and the role of pharmacists about dermocosmetic products in Türkiye. In the study the term "dermocosmetic" was used because in Türkiye a dermocosmetic trend was created assuming it to be more catchy and drug-like. Face to face survey method was used. The data was collected with a questionnaire in three days during the Farmavizyon Pharmacy Fair, Istanbul, 2007. A total number of two hundred seventy six respondents have attended, of which one hundred fifty six were female and one hundred nineteen were male passersby from forty one of eighty one cities of Türkiye. The findings were transferred to electronic documents and analyzed by descriptive statistics and $\chi^{2}$ tests by using the SPSS 11.5 PC software.

Key words: Pharmacy Services, Community pharmacists, Cosmetic, Cosmeseutics, Social pharmacy.
\end{abstract}




\section{ÖZET}

Bu çalışma, Türkiye'deki eczane eczacılarının dermokozmetikler hakkındaki bilgi düzeylerini tespit etmeyi amaçlamaktadır. Diğer hedefler ise dermokozmetik pazarında eczacıların rolünü belirlemek ve bu piyasa ile ilgili durum tespitinde bulunmaktır. Bu çalışmada kullanılan veriler, Istanbul Farmavizyon Eczacılık Fuarı 2007'de üç gün boyunca yapılan bir anket ile toplanmıştır. Bu amaçla, kırkbir farklı ilden gelen eczacılar arasından, yüzellialtısı bayan, yüzondokuzu bay olmak üzere rastgele seçilmiş toplam ikiyüzyetmişaltı kişiyle görüşülmüştür. Elde edilen veriler SPSS 11.5 istatistik programı ile değerlendirilip tartışılmıştır.

Anahtar kelimeler : Eczacılık Hizmetleri, Eczane eczacllarl, Kozmetikler, Kozmesötikler, Sosyal eczacllik.

\section{INTRODUCTION}

Cosmetics have a colorful history reaching back to ancient times, used for artistic, beautifying, protective, decorative, cleansing, camouflaging, and ceremonial purposes (1). After World War I Anglo-American taboos against makeup were rejected and new products and techniques of manufacture, packaging, and advertising have made cosmetics available (2). Also throughout history men and women search to use the medicinal power of natural compounds to increase their health, enhance their looks and fight off aging (3) and the use of cosmetics was thought to enhance, rather than create, beauty (1).

New perceptions about the function of the skin, as well as the development of new products for skin care, make it imperative to define cosmetics and drugs. In different countries, different definitions of cosmetics are used, while the definition of a drug is more or less equivocal in these countries (4).

Recently the global trend in the cosmetics industry is toward developing "medicinally" active cosmetics, and in the pharmaceutical industry it is, in reverse, toward "cosmetically" oriented medicinal products as part of a current "life-style" ideology (5). And in "modern society", consumers moved away from conventional products to meet the promises of futuristic technology inspiring scientific improvement in the world of "cosmeceuticals", which ideally combine both worlds: wellness and beauty, ancient traditions and new science. At this intersection, definition of the term "cosmeceutical", coined in the 1960s by Raymond Reed and popularized by Albert M. Kligman, which has no official or regulatory definition $(3,6,7)$. The cosmeceuticals, serving as a bridge between cosmetics and pharmaceuticals (8), containing biologically active ingredients and 
claiming to have medicinal or drug-like benefits rapidly advanced, especially after the identification of alpha hydroxyl acids as anti-wrinkle agents (7).

Today as "cosmeceuticals" is the fastest growing segment of the cosmetics industry (8) with the loopholes in the regulations concerning labels providing misleading information to the consumer and marketers making endless claims. Information printed on the label make consumers believe a product is simply safe because the manufacturer says it is so or do not realize that the great design and pretty colors of the label are often hiding toxic chemicals.

As cosmetics are the source of daily, population-wide and often long-term exposure to a variety of substances (9), other important concerns for cosmetic products are safety and efficacy. Post-marketing vigilance systems for cosmetic products with a special consideration for notification of adverse reactions are missing in most countries. All those problems are because the regulations of cosmeceuticals have not been evaluated and harmonized yet between countries (5), but a trend is growing toword uniformity (10).

Those mentioned points inspired researcherers to conduct survey research among community pharmacists to depict their level of knowledge on cosmeceuticals, as the demand is soaring for this kind of sophisticated skin treatments that do more than camouflage imperfections, by putting in the words the term "dermocosmetics", which is mostly used in Türkiye's cosmetic industry, instead of the term "cosmeceuticals".

There is a similar border dividing drugs and cosmetics as the one dividing drugs and foods, often defined as "the grey area" or the products themselves as "borderline products". Terms have not coined to describe all of the oral and topical products within the border areas including "cosmeceuticals".

Different laws and regulations apply to each type of product according to the legal difference between a cosmetic and a drug which is determined by its intended use. Companies sometimes break the law by marketing a cosmetic with a drug claim or by marketing a drug as if it is a cosmetic, without adhering to requirements for drugs (11).

Cosmetics are defined by their intended use, as "articles intended to be rubbed, poured, sprinkled, or sprayed on, introduced into, or otherwise applied to the human body for cleansing, beautifying, promoting attractiveness, or altering the appearance" by the Food, Drug, and Cosmetic Act (12) . The products included in this definition are: skin moisturizers, perfumes, lipsticks, fingernail polishes, eye and facial makeup preparations, shampoos, permanent waves, hair colors, 
toothpastes, and deodorants, as well as any material intended for use as a component of a cosmetic product (11).

The term "cosmeceutical" is atributed to Dr. Albert M. Kligman, a professor at the University of Pennsylvania Medical School, and a dermatological researcher, who introduced it in 1984 at the National Scientific Meeting of the Society of Cosmetic Chemists (13) and identified the category as a hybrid of products lying on the spectrum between drugs and cosmetics (8) and whether pro or con, his term entered the vocabulary of skin care science (13).

In Europe, the existence of cosmeceuticals is not accepted, claiming the term to be little more than a US marketing gimmick. Be that as it may, for the purposes of this study, cosmeceuticals were used as "dermocosmetics" and as "a category of cosmetic products that produce or claim to produce therapeutic benefits." These may be physiological or even psychological (14). According to the Gesellschaft für Dermopharmazie (Society for Dermopharmacy), Germany, the term "dermocosmetics" designates measures for the care, protection and cleansing of skin for which the application purpose is achieved under coconsideration of dermatological and pharmaceutical aspects (15).

\section{RESEARCH OBJECTIVES AND METHODS}

This study aims to determine, community pharmacists' levels of knowledge and the role of pharmacists with dermocosmetic products.

The design of the study can be characterized as both descriptive and determinative. It is an attempt to describe how community pharmacists view dermocosmetic products and which criteria make them display the products in their pharmacy. It is determinative in terms of the attempt to put forward data on dermocosmetics' current state.

\section{Study Area}

This study took place at Farmavizyon Pharmacy Fair in CNR Expo Center on 13-15 April 2007, Istanbul, Türkiye. The fair was organized by the Turkish Pharmaceutical Association (Türk Eczacıları Birliği: TEB) and Pharmacist's Cooperation (Tüm Eczacı Kooperatifleri Birliği: TEKB), and has the speciality of being a unique fair that is constituted by pharmacist organizations. The objective of the Farmavizyon Pharmacy Fair is to bring together pharmacists, new products, projects and activities in drug and pharmaceutical subjects with all components of 
the sector, to inform the sector about all actions and improvements directed to the pharmaceutical sector in Türkiye and to promote the pharmacist's vocational development (16).

\section{Population and Sample}

The population was, community pharmacists who were visiting the Fair. Passersbys were randomly asked for consent by the interviewers, if he/she would like to answer the questionnaire, and asked if he/she is community pharmacists or not. The ones, who were not a community pharmacist excluded. The questionnaire was administered to those who agreed to answer and was a community pharmacist. At the end of the second day, most of the attendents were included in the survey.

\section{Data Collection}

The survey was composed of two parts. In the first part, there were questions for hypothesis testing, which were both closed and open ended. The second part included demographic and descriptive questions.

There were no restrictions about gender and age of respondents, except pharmacy ownership positions. The questionnaire aimed to explore the level of knowledge and attitudes on dermocosmetic products and demographic characteristics. The questions were asked in an interviewing environment. Face to face interviews were done by twenty-eight (14 groups) trained students of Yeditepe University Faculty of Pharmacy. The students took 3 hours training on survey methods, including work shops. The study was also a training opportunity for the students.

\section{DATA ANALYSIS TECHNIQUE}

The findings were transferred to electronic documents and analyzed by descriptive statistics and chi-square $\left(\chi^{2}\right)$ tests by using the SPSS 11.5 PC software.

\section{RESULTS}

A total of 282 questionnaires were completed. 6 of them were not included as most of the questions were not answered properly. 276 of the surveys were analysed. Unanswered questionnaires were set apart from the analyses and tables. 


\section{Demographic Characteristics}

A total of 156 female and 119 male respondents were interviewed. $56.7 \%$ of the respondents were female and $43.3 \%$ were male. Our findings are similar to the gender distribution of pharmacists in Türkiye that is $52.7 \%$ female and $47.3 \%$ male (17).

Table 1. Gender

\begin{tabular}{lllll}
\hline & Frequency & Percent & Valid Percent & Cumulative Percent \\
\hline Female & 156 & 56,5 & 56,7 & 56,7 \\
Male & 119 & 43,1 & 43,3 & 100,0 \\
Total & 275 & 99,6 & 100,0 & \\
\hline
\end{tabular}

As seen in Table 2, most of the respondents $(\sim 80 \%)$ are between the ages of 30 and 60 . Number of the respondents aged greater than 60 and less than 30 are almost equal.

Table 2. Date of Birth

\begin{tabular}{lllll}
\hline & Frequency & Percent & Valid Percent & Cumulative Percent \\
\hline $1940-1949$ & 26 & 9,4 & 9,5 & 9,5 \\
$1950-1959$ & 98 & 35,5 & 35,6 & 45,1 \\
$1960-1969$ & 74 & 26,8 & 26,9 & 72,0 \\
$1970-1979$ & 49 & 17,8 & 17,8 & 89,8 \\
$1980-1989$ & 28 & 10,1 & 10,2 & 100,0 \\
Total & 275 & 99,6 & 100,0 & \\
\hline
\end{tabular}

The respondents are from the 43 of 81 different cities of Türkiye. Most of the participants are from Istanbul ( $n=91)$, Bursa $(n=26)$, Izmir $(n=19)$, Ankara $(n=11)$ and Balıkesir $(n=10)$. It can be easily seen that the cities with the most participation are very close to Istanbul geographically. There are also repondents from distant cities.

Most of the respondents defined the location of their pharmacies as "District/Neighborhood" and "Downtown District" (both 26.8\%, $\mathrm{n}=74$ ). 
Table 3. Location of the Pharmacy

\begin{tabular}{|c|c|c|c|c|}
\hline & Frequency & Percent & Valid Percent & $\begin{array}{l}\text { Cumulative } \\
\text { Percent }\end{array}$ \\
\hline Near Hospital & 49 & 17,8 & 17,8 & 17,8 \\
\hline $\begin{array}{l}\text { Near Cottage Hospital/Village } \\
\text { Clinic }\end{array}$ & 63 & 22,8 & 22,8 & 40,6 \\
\hline District/Neighborhood & 74 & 26,8 & 26,8 & 67,4 \\
\hline Downtown District & 74 & 26,8 & 26,8 & 94,2 \\
\hline Other & 16 & 5,8 & 5,8 & 100,0 \\
\hline Total & 276 & 100,0 & 100,0 & \\
\hline
\end{tabular}

The respondents were asked to write in the area of their pharmacies in meter squares. Subgroups ranged from 20 to $1000 \mathrm{~m}^{2}$, so in order to force subgroups into more equal numbers allowing for a more meaningful statistical analysis, original subgroups were abandoned and the respondents' answers were recorded into collapsed categories. $35.0 \%$ of the respondents reported the area of their pharmacies as between 40 and 59 square meters. $21.2 \%$ indicated it between 20 and 39 square meters. Earlier (before 1993) pharmacies could be opened in a 20 square meter area, because of that there are still pharmacies which have $20 \mathrm{~m}^{2}$. At the present a pharmacy should be 35 square meters and bigger (18), that is to say most of the respondents' pharmacies are bigger than the minimum legal area.

Table 4. Area of the Pharmacy $\left(\mathrm{m}^{2}\right)$

\begin{tabular}{cllll}
\hline $\mathbf{m}^{\mathbf{2}}$ & Frequency & Percent & Valid Percent & Cumulative Percent \\
\hline $20-39$ & 58 & 21,0 & 21,2 & 21,2 \\
$40-59$ & 96 & 34,8 & 35,0 & 56,2 \\
$60-79$ & 52 & 18,8 & 19,0 & 75,2 \\
$80-99$ & 27 & 9,8 & 9,9 & 85,0 \\
$100-119$ & 17 & 6,2 & 6,2 & 91,2 \\
$120-139$ & 11 & 4,0 & 4,0 & 95,3 \\
$140+$ & 13 & 4,7 & 4,7 & 100,0 \\
Total & 274 & 99,3 & 100,0 & \\
\hline
\end{tabular}

Most of the respondents (29.5\%) stated that they employ two staff in their pharmacy. More than $80 \%$ of the respondents employ 1 to 4 staffs in their pharmacies. There were also pharmacists working with 20 staff, while some were working alone. 
Only 5\% of the respondents stated that they employ an assistant pharmacist in their pharmacies, while $95.1 \%$ of them noted that they do not. It seems that community pharmacists rarely prefer to work with an assistant pharmacist. In the years ahead, it can be obligatory to employ an assistant pharmacist by law or it can be a must because of workload.

Table 5. Number of Staffs

\begin{tabular}{lllll}
\hline & Frequency & Percent & Valid Percent & Cumulative Percent \\
\hline 0 & 4 & 1,4 & 1,5 & 1,5 \\
1 & 36 & 13,0 & 13,3 & 14,8 \\
2 & 80 & 29,0 & 29,5 & 44,3 \\
3 & 54 & 19,6 & 19,9 & 64,2 \\
4 & 47 & 17,0 & 17,3 & 81,5 \\
5 & 22 & 8,0 & 8,1 & 89,7 \\
6 & 11 & 4,0 & 4,1 & 93,7 \\
7 & 11 & 4,0 & 4,1 & 97,8 \\
9 & 3 & 1,1 & 1,1 & 98,9 \\
10 & 1 &, 4 &, 4 & 99,3 \\
12 & 1 &, 4 &, 4 & 99,6 \\
21 & 1 &, 4 &, 4 & 100,0 \\
\hline Total & 271 & 98,2 & 100,0 & \\
\hline
\end{tabular}

This question was also asked for the respondents to write in how long they have been a community pharmacist and subgroups ranged from months to 44 years. Most of the respondents worked more than 10 years as a community pharmacist.

$40.1 \%$ of the respondents stated that they worked in different jobs before opening their pharmacy. Among $40.1 \%$ of the respondents, who noted that they worked in other jobs before opening their pharmacies, $27.9 \%$ stated that they worked in the "Health Sector" and $12.3 \%$ in other sectors. Here "Health Sector" refers to hospital, pharmaceutical wholesaler, responsible directorship, Social Security Agency (SSK), pharmaceutical company, pharmacy (as an assistant pharmacist-trainee) and pharmacist organizations; "Other" refers to public occupation, commerce and the military. This is an interesting result, as pharmaceutical industry managers generally stated that, it is difficult for them to work with pharmacists as they can easily quit work to open their own pharmacies. 
Table 6. The Job before Being a Community Pharmacist

\begin{tabular}{llll}
\hline & Frequency & Percent & $\begin{array}{c}\text { Cumulative } \\
\text { Percent }\end{array}$ \\
\hline Did not worked in another job before & 165 & 59,8 & 59,8 \\
Health Sector & 77 & 27,9 & 87,7 \\
Other & 34 & 12,3 & 100,0 \\
Total & 276 & 100,0 & \\
\hline
\end{tabular}

Most of the respondents $(48.0 \%)$ defined the term "dermocosmetics" as personal care, beauty, cosmetic, anti-ageing, make-up and life. Respondents seem to give scientific definitions $(34.9 \%)$ to the term and defined it as medical, half-drug, scientific, treatment, drug, dermatology, dermis, science, cosmetology, clinically tested, active ingredient and cosmeceuticals. Respondents who are inclined to economic occasions (5.9\%) defined it as extra income, product diversity, customer satisfaction, money and market. Some of the respondents gave definitions as natural, herbal, alternative medicine and organic (2.2\%). Only a few respondents $(3.7 \%)$ added cosmeseuticals is a profession for pharmacists, because it is the only profession that took cosmetic lectures at faculty. Those respondents also gave the answers that those products should be sold under control of a health care professional such as pharmacists and dermatologists (Figure 1).

Many of the respondents noted that they are not selling dermocosmetic products (56.9\%). While $43.1 \%$ of the respondents pointed out that they provide dermocosmetics in their pharmacies.

The respondents who are selling dermocosmetic products in their pharmacies stated that they provide those products because they do place reliance on them. Both selling and not selling respondents showed the reason "location" (75.3\%). The respondents who are not selling dermocosmetic products stated that there was no demand and their sales were only prescription based.

Dermocosmetic Definition

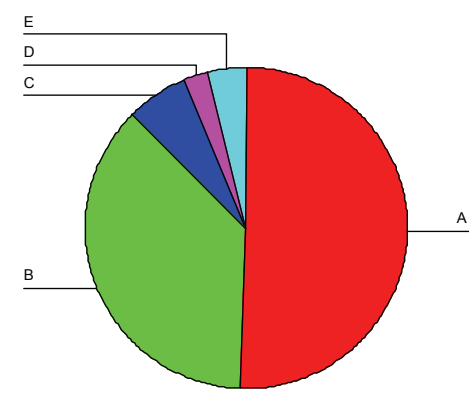

A: Personal Care, Beauty, Cosmetic;

B: Half Drug, Scientific, Medical

C: Extra Income, Product Diversity, Customer

Satisfaction

D: Natural, Herbal, Alternative Medicine

E: Related to Pharmacist and Dermatologists

Figure 1. Dermocosmetic Definition 
Table 6. Reason of Selling/Not Selling

\begin{tabular}{lllll}
\hline & Frequency & Percent & Valid Percent & $\begin{array}{l}\text { Cumulative } \\
\text { Percent }\end{array}$ \\
\hline Location & 64 & 23,2 & 75,3 & 75,3 \\
No Demand & 15 & 5,4 & 17,6 & 92,9 \\
Reliance & 3 & 1,1 & 3,5 & 96,5 \\
Prescription & 3 & 1,1 & 3,5 & 100,0 \\
Total & 85 & 30,8 & 100,0 & \\
\hline
\end{tabular}

Most of the respondents $(60.2 \%)$ stated that they began selling dermocosmetic products in the last 5 years; this can be an indicator for the growth of the dermocosmetics market and also the great revolution in health and pharmaceutical legislation for the last 5 years.

Some of the respondents (32.4\%) put forward the economical rationale and stated frankly that they prefer to sell dermocosmetic products because of extra income, money and their profitability rates and of also being different from colleagues. $28.8 \%$ noted that there is demand and the location of their pharmacy is suitable for selling. The respondents thought "dermocosmetics job" is related to pharmacist (21.6\%), for they are taking lectures on cosmetology at faculty, and $11.7 \%$ found those products reliable, useful and believable and in their field of interest. Some $82.2 \%$ of respondents stated that they are giving consultancy on dermocosmetic products, while $17.8 \%$ are not.

Among 276 respondents 119 declared that they sell dermocosmetics. About $57.1 \%$ of 119 respondents do not employ specified staff for dermocosmetic products, while $42.9 \%$ do, and $87.0 \%$ of the $42.9 \%$ of respondents indicated that they mostly employed "1" staff who is specified on dermocosmetic products.

As seen in Table 7 most of the respondents remarked that their customers decided to buy a dermocosmetic product mostly after watching television advertisements and seeing press advertisements. Other decision factors that effect customers are in order: dermatologist, friends, display windows of pharmacies and internet.

$85.5 \%$ of the respondents noted that they request scientific information about the dermocosmetic products, which they are going to provide in their pharmacy.

Most of the respondents (85.5\%) reported that they request scientific information from dermocosmetic companies. They requested some kind of literatures to become informed, because they feel themselves responsible to inform their customers (88.2\%). Most of the respondents 
indicated that they sell dermocosmetics more by their consultancy (OTC), less by dermatologist prescriptions. Nearly all of the respondents noted that they sold dermocosmetics by their consultancy $(87.0 \%)$.

Table 7. Decision Factors

\begin{tabular}{ll}
\hline Decision Factors & Frequency (n)* \\
\hline Television Advertisements & 84 \\
Press Advertisements & 67 \\
\hline Dermatologist & 58 \\
\hline Friends & 44 \\
\hline Display Windows of Pharmacies & 38 \\
Internet & 19 \\
Other & 12 \\
Product Package & 7 \\
\hline
\end{tabular}

*: Respondents could chose three options. Most mentioned ones could be seen without proportions.

Most of the respondents reported their level of knowledge on dermocosmetic products as "moderate" (39.3\%). It was assumed that the community pharmacist should have at least moderate level of knowledge.

Table 8. Knowledge Level

\begin{tabular}{lllll}
\hline & Frequency & Percent & Valid Percent & $\begin{array}{l}\text { Cumulative } \\
\text { Percent }\end{array}$ \\
\hline Great & 23 & 8,3 & 8,4 & 8,4 \\
Good & 53 & 19,2 & 19,3 & 27,6 \\
Moderate & 108 & 39,1 & 39,3 & 66,9 \\
Poor & 83 & 30,1 & 30,2 & 97,1 \\
None & 8 & 2,9 & 2,9 & 100,0 \\
Total & 275 & 99,6 & 100,0 & \\
\hline
\end{tabular}

The $60.0 \%$ of respondents noted that they are using a dermocosmetic product(s), while $40.0 \%$ noted that they are not.

The respondents, who are using a dermocosmetic product(s), stated that they are using them for personal care $(52.5 \%)$. The respondents, who are not using a dermocosmetic product(s), claimed that he/she does not need to use one $(25.3 \%)$ or does not believe/trust in those products.

Vichy is the most preferred brand by the respondents $(n=47)$. In table 17 merged companies Vichy and L'Oréal were written separetly because both were declared as so. 
Price was given as the main criteria for respondents to choose a brand or a company.

As shown in Table 10 respondents obtain education mostly from companies $(n=55)$. This was an expected result, but it is important if this kind of education can be accepted as scientific. Interestingly two of the respondents mentioned that they do not need education, because they do give lectures and also arrange meetings on dermocosmetics.

Table 9. Dermocosmetic Brands Found in Pharmacies

\begin{tabular}{ll}
\hline Brand Name & Frequency (n)* $^{*}$ \\
\hline Vichy & 47 \\
\hline La-Roche Posay & 32 \\
\hline Sebamed & 31 \\
\hline Aven & 15 \\
\hline Nivea, Roc & 11 \\
\hline Bioder & 7 \\
\hline Mustela, L'Oréal & 6 \\
\hline Bioxin, OHT, Skin Code, Babe, DDF & 5 \\
\hline Pharma 7, Dr. Murad, MD Formulations & 4 \\
\hline Kinerase, Neutrogena, Imedeen, M. Asam & 3 \\
Mavala & 2 \\
\hline Skin Doctors, Exfoliac, Hydroderm, Noviderm, Vivatinel, Bioderma, & 1 \\
Benev & \\
\hline
\end{tabular}

Table 10. Education on Dermocosmetics

\begin{tabular}{ll}
\hline Education & Frequency (n)* \\
\hline Companies & 55 \\
Pharmacist Organizations & 16 \\
Faculty & 15 \\
Other & 14 \\
Not Educated & 8 \\
Give Educations, Arrange Meetings & 2 \\
\hline
\end{tabular}

Most declared reasons for brand selecting of the respondents are "prescriptions of dermatologists" and "demands of customers"; nevertheless these factors were also affected by companies' advertisements. Therefore advertisements affect both dermatologists and pharmacists, also the patients/customers. 
Respondents believe dermocosmetic products have all clinical trials and strict legislations. But it does not mean that the regulations are sufficient and efficient as it is in drugs. The respondents intended by "company support" that in an emergency situation (as a patient get allergy from a dermocosmetic product etc.) company should take its responsibility and support the community pharmacist.

Community pharmacists and customers also look for safety (reliable), efficacy (efficiency) and quality (of good quality, easy to use) from dermocosmetic products as for drugs. Differently eight of the respondents stated that the customers look for a miracle from dermocosmetic products. This can be due the advertisements of the dermocosmetic companies. Claims in advertisements as "short time - quick effect" make customers seek for a miracle, but this can not be possible all the time.

Pharmacists look for price at first glance while the customers for efficiency. This may be the main reason why the market is growing very rapidly.

\section{DISCUSSION}

This study provides information on cosmeceuticals and cosmetic aspects of community pharmacists in Türkiye.

The results highlight how aspects of the community pharmacist can influence dermocosmetic product sales and their patients/customers to purchase those kinds of products, thus pharmacists' level of knowledge about dermocosmetics is of great importance. In particular, the results point to the role of the female community pharmacists in expected gender counts in shaping dermocosmetic product use and sales. The community pharmacists should be directed to the training elements to get knowledge of dermocosmetics: the key factor that currently effects patients/consumers, hence the authorities, academicians and pharmacy organizations should keep providing educational and/or training opportunities.

Cosmeceuticals are a marriage between cosmetics and pharmaceuticals but manufacturers cannot maintain that a cosmeceutical product has drug-like qualities. In such case, it is no longer considered a cosmeceutical but a drug, which requires review and approval for distribution by regulatory bodies such as the Food, Drug, and Cosmetic Act (FDA) in the U.S. and regulatory agencies in the EU countries. While the FDA does not recognize the term "cosmeceutical," the cosmetic industry uses this word to refer to cosmetic products that have medicinal or drug-like benefits. The Ministry of Health in Türkiye, in accordance with the Cosmetics Act, is the body 
authorized to consider and make recommendations in all cosmetic products on the market and all their drug like qualities and to determine cosmetic terminology and also to consider all applications against consumer health based criteria.

This study provides an important step towards understanding Turkish pharmacist situation towords dermocosmetic products. Finally it is obvious that more researches are needed through further in-depth qualitative and quantitative research at faculty of pharmacies by academicians as independent researchers on the cosmetovigilance, sales, consumption and efficacy issues of dermeocosmetics in other words cosmeseuticals.

\section{CONCLUSIONS}

The market has also expanded considerably and consistently in the last few years in Türkiye like all around the world. We have indeed entered the era of "cosmeceutical everything". The biggest challenge currently faced by the cosmetic world globally and also in Türkiye by community pharmacists and cosmeceutical industry as they all should learn how to handle a situation with great delicacy and care by considering the scientific point of view and following the world regulatory changes and new scientific approaches.

Besides, while drugs are subject to a review and approval process by authority, cosmetics are not approved by the authority prior to sale. In contrast, cosmeceuticals do not require regulatory approval and consumers can purchase them without a prescription.

In this highly regulated and inter-related modern world, however the confusing and contradicting global regulatory definitions, the cosmetic product developers has to work hard and to use sophisticated ingredients and new technologies that promise to help cosmetic industry with the best cosmetic products.

\section{REFERENCES}

1. Oller, L., " Perceptions of product safety as influenced by product labels for cosmetics" Oklahoma State University, Master of Science Thesis, Tulsa, (2001)

2. Newgreen, B.D., Review of the regulation of products at the interface between cosmetics and therapeutic goods, Australian Government Department of Health and Ageing Therapeutic Goods Administration, Woden ACT, (2005). Available from: http://www.tga.gov.au/consult/2005/cosmeticrepdr.pdf (date of access: 15.06.2008) 
3. Granato, H., Inside Cosmeceuticals. Cosmeceuticals: at the intersection of nutrition and beauty, March 2007. Available from: http://www.insidecosmeceuticals.com/articles/antiaging/7ch49223882759.html (date of access: 21.04.2008)

4. Vermeer, B.J., Definition. In: Elsner P, Maibach HI (eds). Cosmeceuticals: Drugs vs. Cosmetics. Marcel Dekker, New York - Basel, pp 9-13,(2000).

5. Dureja, H., Kaushik, D., Gupta, M., Kumar, V., Lather, V., " Cosmeceuticals: an emerging concept" Indian. J. Pharmacol. 37, 155-159 (2005)

6. Ligade, V.S., Sreedhar, D., Manthan, A., Udupa, N., "Cosmeceuticals: science or marketing?" Current Science, 92,1030-1031 (2007). Available from: http://www.ias.ac.in/currsci/apr252007/1030a.pdf (date of access: 13.03.2008)

7. Bridgehead Consulting. Wang R: Cosmeceuticals: cosmetics? pharmaceuticals? Available from: http://pharmalicensing.com/public/articles/view/1124121306_4300bada8254d (date of access: 12.12 .2007$)$

8. Choi, C.M., Berson, D.S., “ Cosmeceuticals” Semin Cutan Med and Surg, 3,163-168, (2006)

9. Hall, B., Tozer, S., Safford, B., Coroama, M., Steiling, W., Leneveu-Duchemin, M.C., McNamara, C., Gibney, M., "European consumer exposure to cosmetic products, a framework for conducting population exposure assessments" Food. Chem. Toxicol., 45, 2097-2108 (2007)

10. Wilkes, P.D., Legislation and safety regulations for cosmetics in the United States, the European Union and Japan. In: Butler H (ed). Poucher's Perfumes, Cosmetics and Soaps. $\left(10^{\text {th }}\right.$ Ed.) Kluwer Academic Publishers, Great Britain, pp 625-645 (2000)

11. Is it a cosmetic, a drug, or both? (or is it soap?), Office of Cosmetics and Colors, U.S. Food and Drug Administration Center for Food Safety and Applied Nutrition, (2002). Available from: http://www.cfsan.fda.gov/ dms/cos-218.html (date of access: 12.12.2007)

12. U.S. Food and Drug Administration. Food, Drug, and Cosmetic Act, sec. 201(i). (1938).

13. Kligman, A.M., Cosmeceuticals: Do We Need a New Category? In: Elsner P, Maibach HI (eds). Cosmeceuticals: Drugs vs. Cosmetics. Marcel Dekker, New York - Basel, pp 9-13, (2000)

14. Functional Ingredients. Philips L: Cosmeceuticals taking root in Europe. 2002. Available from:http://www.functionalingredientsmag.com/fimag/articleDisplay.asp?strArticleId=19\&st rSite=FFNSite (date of access: 10.11.2007) 
15. Guidelines "Dermocosmetics for the Cleansing of Dry Skin", Department of Dermocosmetics, Gesellschaft für Dermopharmazie (Society for Dermopharmacy), Issue March 2001. Available from: http://www.gd-online.de/english/fgruppen e/kosmetik_e/trockenehaut_e.htm (date of access: 12.05.2008)

16. See about Farmavizyon. Available from: http://www.farmavizyon.com/?modul= farmavizyon\&act=gecmis (date of access: 08.02.2008)

Received: 09.02.2010

Accepted: 06.06.2010 